\begin{tabular}{|lcc|}
\hline \multicolumn{3}{|c|}{ TOTOBUANG } \\
\hline Volume 5 & Nomor 1, Juni 2017 & Halaman 33-44 \\
\hline
\end{tabular}

\title{
SAPAAN DALAM PERTUNJUKAN WAYANG KULIT STUDI KASUS: PERTUNJUKAN WAYANG KULIT CANTRIK DURNA OLEH TIMBUL HADIPRAYITNA \\ (Address in Leather Puppet Performance Cases Study: Performance of Wayang Kulit Cantrik Durna by Timbul Hadiprayitna)
}

\author{
Kurnia Ayu P. T. H. \\ Universitas Negeri Surabaya \\ Jalan Lidah Wetan, Lakarsantri, Surabaya, Jawa Timur \\ Pos-el: kurniaayupth@gmail.com
}

(Dikirim: 29 Maret 2017; Direvisi: 18 Mei 2017; Diterima: 7 Juni 2017)

\begin{abstract}
This article is about a research study conducted to describe the system, type, and function of form of address in wayang kulit, the Javanese leather-puppet shadow play. The subject under study was a recording of such a play titled Cantrik Durna performed by Timbul Hadiprayitna as the puppet master. The research method applied was descriptive in nature. The research data were obtained by means of a listen-and-write technique and analyzed by means of contextual interpretation. The research result are as follows the system of form of address in wayang kulit consists of aspects of (1) relation between the addresser and addressee, (2) sex/gender, (3) setting (place,time, and atmosphere), (4) honoring, (5) doer, vocation, or profession.

Keywords: term of adress, leather puppet performance, cases study

Abstrak

Artikel ini adalah tentang penelitian yang dilakukan untuk menggambarkan sistem, jenis, dan fungsi dari sistem sapaan dalam wayang kulit Jawa. Subjek yang diteliti adalah rekaman pertunjukan wayang kulit yang berjudul Cantrik Durna dilakukan oleh Timbul Hadiprayitna sebagai dalang. Metode penelitian yang diterapkan adalah deskriptif. Data penelitian diperoleh dengan tehnik menyimak dan menuliskan serta dianalisis dengan menggunakan interpretasi kontekstual. Hasil penelitian adalah sebagai berikut: sistem sapaan dalam wayang kulit terdiri dari aspek (1) hubungan antara penyapa dan tersapa, (2) jenis kelamin, (3) latar (tempat, waktu, dan suasana), (4) penghormatan, dan (5) pelaku/pekerjaan.
\end{abstract}

Kata-kata Kunci: sapaan, pertunjukan wayang kulit, studi kasus

\section{PENDAHULUAN}

Tannen (1996:14) mengatakan bahwa hidup adalah perkara menghadapi orang lain, baik itu dalam hal yang sangat penting ataupun dalam hal yang sepele, misalnya berbasa-basi. Crysral (1980:264) menyebut basa-basi dengan istilah fungsi fatis atau phatic function. Fungsi fatis adalah fungsi bahasa yang cenderung digunakan sebagai sarana kontak sosial daripada untuk bertukar informasi atau menatakan ide. Bentuk-bentuk kegiatan seperti salam,sapaan,panggilan atau memanggil merupakan suatu kegiatan yang menimbulkan kontak sosial, sehingga bentuk-bentuk semacam ini termasuk dalam bentuk fatis. Pernyataan Crystal tersebut sejalan dengan penjelasan Malinowski (dalam Kartomihardjo, 1988:27 dan Alwasilah, 1985:28) yang menyatakan bahwa salam dan sapaan termasuk ke dalam fungsi fatis atau phatic communication.

Dalam wayang kulit sistem sapaan belum banyak dikaji. Untuk itu ada peluang mengkaji sistem sapaan dalam wayang kulit. Adapun hal yang mendorong untuk meneliti hal tersebut adalah (1) belum ada penelitian terhadap permasalahan tersebut; (2) sistem sapaan ini merupakan bagian dari salah satu jenis pertimbangan penentuan bentuk sapaan dalam masyarakat Jawa yaitu fungsi dan tujuan; (3) meskipun berkonsentrasi pada 
bagian kecil yaitu fungsi dan tujuan mempertimbangka pemilihan bentuk sapaan, tetapi justru didalamnya muncul banyak sistem yang tidak digunakan dalam kehidupan sehari-hari masyarakat Jawa.

Sistem sapaan di dalam wayang kulit menunjukkan segala yang bervariasi dibanding dengan sapaan dalam masyarakat Jawa masa kini. Spesifikasi sistem terlihat pada fungsi dan kekhasan bentuk sebagai contoh,munculnya sapaan terhadap Dewa, guru, pejabat tertentu, abdi, golongan masyarakat tertentu dan lain sebagainya.

Fenomena ini akan dikaji dengan judul Sistem Sapaan dalam Wayang Kulit. Hasil penelitian diharapkan dapat melengkapi teori sapaan dalam masyarakat Jawa yang telah ada dan teori komunikasi secara umum.

Berdasarkan uraian latar belakang dan tujuan yang diharapkan. Maka dapat dibuat rumusan masalah sebagai berikut.

1. Bagaimanakah sapaan yang digunakan didalam wayang kulit?

2. Bagaimanakah bentuk sapaan yang digunakan?

3. Seperti apakah fungsi sapaan dalam wayang kulit?

Sesuai dengan rumusan masalah di atas, penelitian ini bertujuan untuk mendeskripsikan:

1. Sistem sapaan yang digunakan di dalam wayang kulit,

2. Jenis atau bentuk sapaan yang digunakan di dalam wayang kulit,dan

3. Fungsi sapaan yang digunakan di dalam wayang kulit.

Wayang berasal dari akar kata yang berarti bayangan. Mayang berarti memainkan bayangan atau pertunjukan bayangan (Mulyono, 1989:51). Pergelaran wayang kulit merupakan salah satu karya seni dan karya sastra yang amat digemari masyarakat. Hal ini di sebabkan oleh pandangan bahwa wayang dipandang sebagai suatu bahasa simbol dari hidup dan kehidupan yang lebih bersifat rohaniah dari pada hidup lahiriah (Mulyono,1989:15).
Apabila seseorang melihat wayang, bukan wayang itu yang dilihat, tetapi lokan atau bayangan diri kita yang seolah-olah masuk dalam lokan tersebut. Hal ini dirasakan saat kita menonton wayang, kita dapat mengoreksi perilaku dan sifat kita lewat toko yang mirip dengan karakter kita atau penonton-penonton yang lain dengan fenomena tersebut setiap penonton secara sadar dapat melihat bayangan toko-toko cerita tersebut.

Berdasarkan uraian tersebut, dapat dilihat bahwa aspek utama yang akan dimainkan dalang adalah permainan komunikasi. Komunikasi yang terjadi adalah komunikasi antar tokoh yang di ceritakan, komunikasi dalang dengan krunya, komunikasi dalang dengan penontonnya, atau juga komunikasi cerita dengan penonton. Sistem komunikasi dalam pakeliran tidak jauh berbeda dengan yang terjadi dalam sistem komunikasi masyarakat jawa, tetapi dalam hal pemilihan sapaan variasi dalam wayang justru lebih beragam.

Pemilihan bentuk sapaan panggilan dan sebutan berkaitan erat dengan martabat seseorang. Orang akan merasa'diorangkan' jika di sapa sesuai dengan stratanya. Oleh karna itu sapaan, panggilan, dan sebutan merupakan salah satu penanda strata sosial yang berkaitan dengan derajat dan martabat seseorang. Orang akan merasa terhina seandainya disapa dengan poyokan, dalam suasana yang resmi, dan akan merasa gembira atau tersipu malu jika hal tersebut disampaikan dalam suasana santai. Oleh karna itu pemilihan bentuk sapaan yang tepat memiliki peranan penting dalam upaya menggambarkan siapa toko tersebut.

Sapaan adalah morfem, kata, atau frasa yang pilih untuk menyatakan hubungan antara penutur dengan mitra tuturdalam suatu percakapan (Kridalaksana, 1984:171). Dalam interaksi sosial, sapaan digunakan secara langsung anatara penutur dan mitra tutur (Crystal, 1980:13). Agar tidak terjadi ketegangan interaksi, maka pemilihan bentuk sapaan yang tepat harus 
ditimbangkan. Apakah seseorang harus menyapa dengan nama diri(first name), dengan gelar, ataukah cukup panggilan akrab saja.

Chaika (1982:45-52) membedakan antara sapaan atau address dengan panggilan atau summons, dan salam atau greettings. Sapaan adalah bagian dari salam yang selalu mengandung kekuasaan. Kekuasaan yang dimaksud adalah penanda jati diri dari penutur. Semakin tinggi tingkat sosial seseorang yang disapa, semakin formaal sapaan yang digunakan. Seseorang tidak akan berani njangkar atau menyapa dengan panggilan akrabnya saja terhadap orang yang lebih tinggi derajatnya.

Aspek di luar kebahasaan yang sangat menentukan pemilihan sapaan adalah faktor sosial. Faktor tersebut misalnya: umur, derajat atau keturunan, jenis kelamin, kekerabatan atau $a w u$, tingkat keformalan, dan status perkawinan (Wijana, 1991:2).

Macam-macam atau jenis sapaan dalam bahasa indonesia dibagi menjadi sembilan yaitu (1) kata ganti seperti aku, kamu, engkau, dia daln lain-lainnya ; (2) nama diri seperti atau nama orang / penutur / mitra tutur ; (3) istilah kekerabatan, seperti ayah, ibu, nenek, anak dan lain-lainnya; (4) gelar dan pangkat seperti dokter, insiyur, guru, jendral ; (5) kata pelaku seperti pembaca, pendengar; (6) bentuk nomina + $\mathrm{ku}$, seperti Tuhan ku, kekasih ku; (7) katakata deiksis atau penunjuk, seperti sini, situ, dan ini; (8) nominan seperti tuan, nyonya, yang mulia; dan (9) zero atau nol seperti pertanyaan mau kemana? di dalam kalimat ini terdapat sapaan bisa saudara, kamu engkau, ibu dan lain sebagainya (Kridalaksana, 1982:14-15).

Wijana (1991) mengklasifikasikan sapaan menjadi tujuh kategori yaitu (1) sapaan yang berupa kata ganti, (2) sapaan kekerabatan, (3) sapaan pekerjaan, (4) sapaan nama diri, (5) sapaan yang berhubungan dengan kasih, sayang dan manis, (6) sapaan yang berkaitan dengan agama, dan (7) sapaan persahabatan.
Kategori sapaan ini di atas memiliki kesamaan dengan sapaan dalam masyarakat Jawa. Berikut ini adalah sapaan dalam bahasa Jawa (Jawa Timur) seperti yang dijelaskan oleh Suprianto (1986) merinci jenis sapaan bahasa Jawa Timur menjadi (1) sapaan yang berupa kata ganti, (2) sapaan yang berupa nama kecil, poyokan, paraban, nama tua atau nama setelah menikah, nama suami, nama anaknya,(3) sapaan karena pangkat,dan jabatan, (4) sapaan kekerabatan, (5) sapaan kekerabatan + elne, dan kata benda.

Kekuasaan sapaan dapat ditentukan oleh status sosial, usia, hubungan kerja seperti atasan dan bawahan,jenis kelamin dan lain sebagainya. Semakin besar kekuasaan seseorang akan menyebkan semakin jauh perbedaan jarak sosialnya. Interaksi yang terjadi seperti dalam pola tersebut dinamakan interaksi veritikal. Selain interaksi vertikal ada juga interaksi yang disebut dengan istilah horisontal. Interaksi horisontal adalah interaksi yang menandai jarak sosial antara penutur dan mitra tutur sangat dekat,sehingga sapaan yang digunakan memiliki rasa kebersamaan atau sederajat dan akrab.

Berdasarkan unsur kekuasaan dan kebersamaan di dalam sapaan, maka pemilihan bentuk sapaan sangat dipengaruhi oleh unsur konteks pembicaraan. Konteks pembicaraan mempengaruhi ketepatan pemilihan sapaan antara lain berupa medan wacana,pelibat wacana, dan sarana wacana (Halliday, 1985, dalam terjemahan Barori Tou, 1994; 16). Pelibat wacana merujuk pada kondisi atau strara sosial orang yang terlibat di dalam pembicaraan. Medan wacana merujuk pada suasana yang terjadi dalam pembicaraan dan apa yang sedang dibicarakan. Adapun sarana wacana merujuk pada bahasa yang digunakan dalam proses percakapan.

Pemilihan sapaan selain ditentukan oleh konteks pembicaraan, dipengaruhi pula oleh kaidah sapaan. Kaidah sapaan dapat digolongkan menjdai 2 yaitu Alternasi dan 
Kookurensi. Kaidah Alternasi bersifat paradigmatik, yaitu kaidah yang berkenaan dengan cara menyapa, dan cara memilih unsur-unsur leksikal yang disesuaikan dengan ciri-ciri orang yang disapa, hubungan penutur dengan mitratutur, dan situasi yang melatarinya. Kaidah Kookurensi adalah kaidah yang berkaitan dengan kesertaan bentuk sapaan dengan bentuk yang lain. Misalnya penggunaan kata tertentu yang disesuaikan dengan situasi dan kedudukan orang yang disapa. Kaidah yang demikian ini adalah kaidah yang bersifat sintagmatik (Ervin Tripp, 1972:213).

Uraian tersebutlah yang melandasi penataan pola atau sistem komunikasi dalam pergelaran wayamg kulit dengan pola komunikasi nyata memiliki kemiripan. Oleh karna itu rambu-rambu teori tersebut dapat dijadikan kerangka pikir untuk mengenali data yang ditemukan.

\section{METODE}

Subjek penelitian adalah rekaman pergelaran wayang kulit Yogyakarta, oleh dalang Ki Timbul Hadiprayitna dari Patalan Bantul, dengan lakon atau cerita Cantrik Durna. Rekaman cerita Cantrik Durna terdiri dari 8 kaset, masing-masing berdurasi 60 menit dalam side A dan B durasi masingmasing 30 menit. Kaset direkam olah Bintang Fajar tahun 1983, dengan izin perindustrian:

200/jateng/01/BINIK/IV/83IK： 2301.02.05 ISIC:3930, terdaftar nomor: 174585. Data penelitian berupa bentuk-bentuk sapaan dan konteksnya.

Pengumpulan data dilakukan dengan teknik simak dan catat. Rekaman disimak dengan cermat dan berulang-ulang, dicatat pola sapaannya dan dicatat sesuai tipe sistem masing-masing. Setelah data tertata kemudian sistem sapaan dalam wayang kulit dilakukan analisis, dan hasilnya dipaparkan secara deskriptif.

Metode penelitian adalah metode deskriptif kualitatif. Analisis dilakukan dengan pemakaian secara kontekstual.
Maksudnya, pendeskripsian atau pemaparan hasil berdasarkan fakta dengan pertimbangan konteks tuturan yang melatari terjadinya tuturan, konteks sosial dan kultural.

\section{PEMBAHASAN}

\section{Hasil penelitian}

Hasil penelitian tentang Sapaan dalam Pertunjukan Wayang Kulit dapat dipaparkan sebagai berikut.

\section{a. Sistem sapaan}

Sistem sapaan dalam wayang kulit terbentuk oleh beberapa aspek penentu seperti berikut:(1)aspek hubungan antara penyapa dan tersapa, (2) aspek jenis kelamin, (3) aspek selting(tempat, waktu dan suasana), (4) aspek tujuan,(5) penghormatan,(6) aspek pelaku, pekerjaan atau profesi,(7) aspek perkawinan dan cinta,(8) aspek penyebutan tampat tinggal,(9) aspek agama dan kepercayaan,(10) aspek penggunaan kata ganti, (11) aspek zero, dan (12) aspek penyebutan identitas khas.

Sistem sapaan yang ditentukan oleh hubungan antara penyapa dan tersapa memiliki beberapa pola hubungan seperti berikut ini. (1) pola hubungan kekerabatan atau dara yang dalam bahasa disebut $a w u$. Hubungan ini ada yang bersifat vertikal dan horisontal, (2) tingkat keakraban, (3) hubungan persahabatan, dan (4) hubungan kerja: majikan dan bawahan.

\section{b. Jenis sapaan}

Bentuk atau jenis sapaan dalam wayang kulit adalah sebagai berikut:(1) sapaan jenis kata ganti, (2) nama diri: nama kecil,nama alternatif atau dasanama, (3) gelar atas kedudukan, (4) sebutan atau panggilan,(5) sapaan keturunan,(6) paraban 'nama keakraban', (7) poyokan 'nama untuk meremehkan/meledek', (8) sapaan profesi, (9) sapaan pelaku, (10) sapaan kasih sayang,(11) sapaan kebanggaan, (12) sapaan persahabatan, (13) sapaan ketidak 
sukaan/jengkel, marah, (14) sapaan perkenalan, (15)

sapaan peprenahan/mbasakke, (16) sapaan yang berhubungan dengan tempat tinggal, (17) sapaan jabatan, (18) sapaan penghormatan, (19)spaan karena hubunagnperkawinan: nama tua, nama suami,nama anaknya (pertama), (20) sapaan untuk Dewa, Dewi, dan Tuhan, (21) sapaan untuk permasuri, (22) sapaan zero, (23) sapaan dalam umpatan, (24) sapaan sebutan khas, (25) sapaan dalam nomina $+\mathrm{mu}$, e, ne, (26) sapaan nominal, (27) sapaan nominal $+\mathrm{ku}$, (28) sapaan yang berkaitan dengan agama, (29) sapaan sebutan kekerabatan + e, ne, (30) sapaan semu/sandiwara dan (31) sapaan penunjuk.

\section{c. Fungsi Sapaan}

Sapaan dalam wayang kulit memiliki beberapa fungsi seperti berikut ini. (1) sapaan yang berfungsi untuk menghormat atau honorifik, (2) sapaan untuk memanggil,(3) sapaan untuk menyebut,(4) sapaan untuk mbasakke, (5) sapaan untuk meledek,(6) sapaan untuk keakraban /mengakrabkan, (7) sapaan untuk menunjukkan asal, (8) sapaan untuk berkenalan, (9) sapaan untuk menciptakan suasana tertentu, (10) sapaan untuk menyindir, (11) sapaan untuk menjelaskan jati diri , (12) sapaan semu untuk bermain drama (sandiwara), (13) sapaan untuk melucu.

\section{Pembahasan}

Seperti yang telah diuraikan pada hasil penelitian,bahwa sistem sapaan dalam wayang kulit memiliki 12aspek penentu sistem, 31 jenis, dan 13 fungsi pembahasan hasil penelitian tersebut dapat di rinkas seperti uraian berikut.

\section{a. Sistem dan Fungsi Sapaan yang Ditentukan oleh Aspek Hubungan Antara Penyapa dengan Tersapa}

Sistem ini memiliki beberapa pola hubungan, yang pertama pola hubungan kekerabatan atau hubungan darah, atau hubungan perkawinan. Pola ini dalam masyarakat Jawa disebut Peprenahan awu. Hubungan darah memiliki alur ke atas dari ego dan alur ke bawah atau bisa disebut vertikal dan horisontal dari ego. Alur kekerabatan vertikan dalam masyarakat Jawa ada tujuh tingkatan atau pitung turunan: anak,bapak,simbah,simbah buyut, simbah canggah, simbah wareng, simbah udheg-udheg, simbah gantung siwur. Apabila dihitung sampai sepuluh tingkat ditambah: simbah gropak sethe, debok bosok, dan gali asem (Tashadi, 1983:24). Alur ini memiliki kesamaan dengan alur kebawah.perbedaannya pada alur ke bawah sebutan simbah 'nenek' diubah putu 'cucu'. Sistem sapaan yang menganut aspektingkatan alur kekerabatan vertikal di dalam penelitian ini hanya ditemukan dua tingkat alur ke atas dari ego dan dua tingkat ke bawah dari ego. Berikut ini adalah kutipan dari masing-masing tingkat.

(1) Duryudana: Rama Prabu Mandaraka, dereng dangu rawuh wonten pakuwon Sewuntana..

Duryudana: 'Ayah Prabu Mandaraka, belum lama datang di perkemahan Sewuntana.'

(2) Janaka: Panahe digawa bapakmu.

Janaka: 'Panahnya dibawa bapakmu.'

Gareng: Panahe ndara nang ngendi Ma?

Gareng: 'Panahnya ndara'tuan' di mana pak?

Gareng: 'Bapak itu kalau bawah panah sukanya ngeri-ngeri' jalan lambat dibelakang'.

Contoh (1) adalah sapaan Duryudana terhadap ayah mertuanya yaitu Prabu Mandaraka. Sapaan rama merupakan ke atas satu tinggkat dari ego. Ego menyapa mertua dengan pilihan kata sapaan rama bukan bapa, karena orang yang disapa memiliki kedudukan tinggi yaitu raja atau prabu, sehingga kata sapaan dipilih yang 
menghormat atau honorifik. Berikutnya pada contoh (2) Janaka menyebut ayah Gareng dengan kata sebutan bapakmu, sebutan ini merupakan sebutan biasa terhadap orang yang berstatus biasa atau mugkin lebih rendah. Janaka berstrata lebih tinggi karena dia adalah majikan sehingga punya kekuasaan memilih sapaan yang dimau. Meskipun demikian Janaka tidak akan memilih kata keng rama 'ayah handamu' kepada Gareng, kecuali Janaka mempunya maksud tertentu misalnya menyindir ataupun sedang marah, pilihan itu bisa saja terjadi, tetapi tidak pada suasana wajar. Pada contoh (2) Gareng menyapa ayahnya dengan sebutan $m a$ 'pak'. Ma merupakan penggalan dari kata rama. Meskipu Gareng mimilih jenis sapaan $M a$ bukan berarti dalam sapaan ini terdapan unsur honorifik seperti yang terjadi pada contoh (1) yaitu penghormatan anak kepada ayahnya. Sapaan ini merupakan sapaan akrab para abdi atau panakawan terhadap ayahnya. Secara konteks sosial pemilihan bentuk penggal atau wancah menandai bahwa hubungan komunikasi terjadi secara biasa atau tidak mengormati. Kategori kata penggal merupakan penanda tingkat tutur madya. Berkomunikasi dengan tingkat tutur madya menunjukkan bahwa didalam komunikasi tersebut terjadi hubungan biasa saja. Berikut ini adalah kutipan sapaan alur vertial keatas dua tingkat dari ego atau tingkatan nenek atau kakek.

\section{Maswapati : Putuku Srikandhikowe raharja?}

Maspati: 'cucuku srikandhi kamu selamat?

Srikandhi : Nuwun inggih pongestunipun eyang Prabu mboten manggih sambekala.

Srikandhi : 'iya atas doa restu kakek Prabu tidak ada halangan'.

Pada contoh (3) sapaan srikandhi terhadap raja Maswapati memilih sapaan honorofik. Sapaan yang biasa digunakan terhadap kakek, dalam masyarakat kecil istilahnya simbah/simbah kakung 'kakek'.
Sapaan ini tidak pas jika dipilih untuk sapaan atau sebutan terhadap oranh berstrata raja. Dalam contoh (3) sapaan Rja Maswapati kepada Srikandhi, merupakan sitem sapaan vertikalke bawah dua tingkat dari ego atau sapaan untuk cucu. Maswapati menyapa Srikandhi dengan sapaan Putuku 'cucuku'. Sapaan ini merupakan sapaan akrab seorang kakek terhadap cucunya. Berbeda jika cucu yang disapa memiliki strata sosial tinggi seperti raja, sapaan yang digunakan pasti berbeda. Berikut ini kutipannya.

\section{Maswapati :Wayah Prabu Bethara Kresna panda kanthi raharja}

Maswapati : 'Wayah 'cucu' Prabu Bethara Kresna selamat'.

Kutipan (4) sapaan yang digunakan Maswapati adalah sapaan nonorifik atau penghormatan.hal ini dilakuka karena Kresna adalah seorang raja yang berkharisma yaitu titisan Wisnu. Oleh karena itu sebutan raja Kresna adalah bethara'sebutan Dewa'. Sapaan kekerabatan alur ke bawah berikutnya adalah satu tingkat ke bawah dari ego yaitu subutan untuk anak, perhatikan kutipan berikut.

(5) Sengkuni: Kawulu nuknun, nuknun inggih dahat dupa nampi pangandika dalem akan Prabunampi pangandika dalem anak Prabu rumentah abdi dalempun bapak

Sengkuni: 'Daulat, siapa menerima perintah ananda Prabu yang diperintahkan kepada hambamu yaitu bapak anda'.

Dalam kutipan (5) sapaan Sengkuni
terhadap Duryudana memilih kata pangandikadalem anak Prabu 'perintahmu ananda Prabu' dengan tujuan untuk menghormati atau sapaan tersebut adalah honorifik. Seorang abdi raja selalu menjunjung tinggi terhadap raja sehingga 
segala ucapan harus bersifat menghormat. Berbeda jika Sengkuni kemenakan yang lain seperti pada kutipan berikut ini.

(6) Sengkuni : Jaya Wikatha, Wikathabala, anane kowe tak timbal maju ngger, panuwunmu natkala dina kang wis kepungkur iki mau bisa tak aturake anak Prabu.

Sengkuni : 'Jaya, Wikatha, Wikathabala, adapun kamu aku panggil menghadap nak, permintaanmu beberapa waktu yang lalu ini tadi bisa aku sampaikan kepada ananda Prabu'.

Sapaan Sengkuni terhadap Jaya Wikatha dan Wikathabala menggunanakan sapaan biasa tanpa ada hormat bahkan Sengkuni menyapa dengan njangkar 'langsung menyebut nama' dan menyebut dengsn kata ganti kowe atau 'kamu' yang menurut konteks sosial Jawa kata kowe bernuansa makna agak remeh. Selain sistem vertikal ada sistem horisontal, seperti berikut ini.

(7) Duryudana: Kaka Adipati Karna, raharju rawuhipun kaka Adipati.

Duryudana: 'Kanda Adipati Karna, selamat datangmu Kanda adipati'.

Duryudana: Kratamarma, prayogakna jeneng para ngadhep ngarsane raka para.

Duryudana: 'Kartamarma, santai sajalah kamu menghadap kakamu’.

Kutipan (7) adalah sapaan Daryudana terhadap Adipati Karna yang berstatus lebih tua sehingga disapa dengan sapaan kakak. Disamping sapaan diatas , yaitu sapaan horisontal untuk laki-laki, ada pula sapaan horisontal untuk wanita. Jenis sapaan horisontal untuk wanita berbeda bentk jika di bandingkan dengan sapaan horisontal terhadap laki-laki. Perhatikan kutipan berikut.
(8) Banowati: Kadangipun kakang dhimas Dursasan, durung suwe kowe ngadhep ana ngarsane pun kakang padha basuke Dursasana.

Banowati: 'Saudara kakak dinda Dursasana, belum lama kau menghadap dihadapan kakanda selamat Dursasana'.

Dursasana: Nuwun pangestunipun kakangbok ratu mboten manggih sambelaka. Pangabekti kula konjuk sahandhaping pepada kakangbok.

Dursasana: 'Iya atas doa restu kanda ratu tidak mendapat alangan. Baktiku aku letakkan dibawah telapak kaki kakanda'.

Kutipan (8) adalah jenis sapaan horisontal terhadap kakak wanita dan adik laki-laki. Banowati menyapa adik iparnya yaitu Dursasana dengan pilihan jenis sapaan yang relatif lebih bebas jika dibandingkan dengan pilihan sistem sapaan bagi Dursasana terhadap Banowati. Banowati secara strata sosial berkedudukan sebagai permaisuri raja, maka dia memiliki kebebasan mreyapa dengan pilihan tingkat tutur apapun. Oleh karena itu pada kutipan diatas, Banowati bisa meyapa dengan sebitan kehormatan dhimas, menyapa dengan kata ganti yang agak kasar yaitu kowe, dan dia juga dapat menyapa dengan nama diri saja atau njangkae Dhimas adalah jenis sapaan penghormatan. Dursasana pantas disapa dengan sapaan hormat Dhimas karena dia seorang pangeran.

Berbeda dengan konteks sosial di atas, Dursasana ketika menyapa Banowita dia harus menggunakan sapaan honorifik yaitu kakangmbok, dan tidak bisa memakai kata mbakyu, atau $y u$ saja. Adapun aspek penyebab hal tersebut adalah konteks strata sosial Dursasana lebih rendah daripada Banowati. Selain sapaan tersebut ada sapaan lain yaitu mbasakke, seperti kutipan berikut ini. 
(9) Gareng: Truk gandheng Bagong mati, neksi Inen kae njur dadi mbakyumu piye?

Gareng: 'Trik karena Bagong meninggal, bagaimana jika si Inen jadi kakakmu?

Sebutan mbakyu pada kutipan (9) merupakan sapaan mbasakke, yaitu Gareng mbasakke Petruk terhadap Innen yang akan diambil istri. Petruk akan menyapa dengan sapaan mbakyu jika si Innen betul jadi istri Gareng.

Sistem sapaan berikut adalah sistem sapaan yang dibentuk oleh aspek hubungan penyapa dan tersapa pada pola tingkat keakraban. Pada pola ini jenis sapaan yang dipilih bedasarkan pada tingkat keakraban hubungan antara penyapa dengan yang disapa. Semakin hormati orang yang disapa maka sapaan yang dipilih penyapa semakin tinggi tingkat penghormatannya. Pilihan tingkat tutur akan dipilih tingkat tutur krama inggil dan diyambah sebutan honorifik. Adapun sapaan pada tingkat sosial yang setara pilihan sapaan jatuh pada jenis biasa saja. Tingkat tutur yang dipilih dalam bisa tingkat tutur: ngoko, madya, ngoko atau krama lugu. Pilihan tingkat tutur ini bersifat adaptasi, artinya pilihan didasari konteks seseai pertuturan yang terjadi. Dalam tingkat keakraban yang erat bisa dipilih krama jika suasaa pertuturan resmi, dan bisa dipilih madya atau ngoko jika suasanya relatif lebih sanpai. Pola seperti ini dalam wayang kulit bisa diliat pada kutipan - kutipan berikut.

(10) Banowati : Togong raharja sowanmu Gong

Banowati: 'Togong selamat menghadapmu Gong'.

Togong: Inggih pangestunipun Gusti mboten manggih smbekala

Togong: 'Iya atas doa restu Gusti tidak memdapat halangan'.

Pada kutipan tersebut penyapa orang yang berstrata sangat tinngi yaitu permasuri dan yang disapa berstrata sosial sangat rendah yaitu abdi. Penyapa pada hubungan ini bebas memilih jenis sapaan, dan yang disapa harus memilih sapaan yang sangat mengormat. Banowati menyapa dengan sebutan nama diri orang yang disapa atau njangkar yautu Togong, sedangkan Togong menggunakan sapaan honorofik yaitu Gusti. Togong tidak bisa memilih sapaan yang lain selain honorifik karena kedudukannya sebagi abdi. Disamping hubungan tersebut ada tingkat hubungan setara atau sederajat dan suasana wajar. Perhatikan kutipan berikut ini.

(11) Janaka: Yen ora sisip panduluku kaya iki kakang Jayawikatha.

Janaka: 'Jika tidak salah penglihatanku ini seperti kakak Jayawikatha'.

Jayawikatha: ora kleru pandugane si adhe

Jayawikatha: 'Tidak keliru dugaan adik'.

Pada kutipan (11) hubungan antara Janaka dan Jayawikatha berpola setara atau relatif tidak membedakan derajat sosial. Mereka sama-sama pangeran keturunan Brahata. Suasana tuturan terjadi pada suasana biasa yaitu pertemuan dijalan/hutan, dan saat itu masih dalam kondisi wajar yaitu saling menyapa. Janaka menyapa dengan sapaankakang, dan Jayawikatha dengan sapaan adhi. Sapaan kakang dan adhi merupakan tingkat sapaan yang setara dan tidak menunjukkan nuansa menghormat, sehingga sapaan yang demikian masuk dalam sistem hubungan keakraban yang sederajat. Pola hubungan berikutnya adalah pola hubungan persahabatan. Berikut ini adalah pola sapaan persahabatan dengan jenis sapaan diri dan jenis zero.

(12) Nirbita: Udawa, nagit ki ambak gamean gampang ning angel iki

Nirbita: 'Udawa, meskipun pekerjaan mudah tetapi sulut mu'.

Udawa: Kejawi nak mamung ndejes niku gampil 
Udawa: 'Kecualu hanay meneteskan air mata itu mudah'

Nirbit: La kuwi rak ora nangis kuwi.

Nirbita: itukan tidak menangis itu'.

Pada kutipan (12) hubungan sosial antara patih Nirbita dan patih Udawa adalah hubungan bersahabatan. Mereka sama-sama patih, sehingga komunikasi yang dibangun bersifat akrab wajar tidak ada unsur penghormatan dan perendahan. Adapun Udawa memilih tingkat tuturan madya karma, secara usia Udawa labih muda. Meskipun demikian suasana komunikasi terbangun wajar, hal ini terlihat pada isi pembicaraan yang begitu santai. Sapaan yang digunakan dalam kutipan (12) adalah sapaan nama diri yauti Udawa dan sapaan zero yaitu Udawa tidak secara eksplsit menyebut nama Nirbita dengan pilihan sapaan tertentu misalnya kakang.

\section{b. Sistem dan Fungsi Sapaan yang Ditentukan oleh Aspek Jenis Kelamin} Jenis kelamin sangat menentukan di dalam seseorang memilih jenis sapaan terhadap orang yang disapa. Jenis sapaan terhadap wanita memiliki ciri khas sebagai penanda gender wanita begitu pula jenis sapaan terhadap pria atau laki-laki. Selain ada bentuk-bentuk khas penanda jenis kelamin, ada pula jenis sapaan yang berlaku secara umum. Maksudnya bentuk ini dapat digunakan untuk menyapa wanita dan pria. Berikut ini adalah kutipan sistem sapaan yang ditentukan oleh aspek jenis kelamin.

(13) Jayawikatha : Paman, paman Harya ingkang putra nungsung.

Jayawikatha: 'Paman, paman Harya ananda ingin tahu..'

(14) Banowati: Bogadenta mati dening dhimas Janaka?

Banowati: 'Bogadenta mati oeleh dhimas Janaka?

(15) Werkudara: Nirbita kakekku 'Nirbita kakekku'
(16) Semar: Ah Gus sedaya kalepatanipun anak kula, mugi ndara paring.

Semar: 'Ah Gus semua kesalahan anakku, semoga tuan memberi..'

(17) Kresna: Diajeng Wara Srikandhi enggal kowe.

Kresna: 'Diajeng Wara Srikandhi cepat kamu..'

(18) Srikandhi: Nanging kakang embok Wara Sembadra.

Srikandhi: 'Tetapi kakang embok Wara Sembadra..'

Sapaan yang digunakan dalam kutipan (13) sampan (16) paman, dhimas, $k a k e k k u$, dan gus adalah jenis sapaan yang di tandai oleh aspek hubungan jenis kelamin laki-laki, sedangkan pada kutipan (17) dan (18) adalah sapaan yang di tandai oleh aspek hubungan jenis kelamin wanita. Adapun jenis sapaan yang menunjukkan dua jenis kelamin adalah sapaan yang bersifat netral seperti : ndara, gusti,yayi, adhi, raka, katakata ganti, dan nama diri. Kutipan yang mendukung bentuk tesebut dapat dilihat pada uraian berikut.

(19) Karna: ...ingkang Raka mboten ketang namung sakedhwping netra, dinten menika ugi nyuwun pamit badhe wangsul dahateng Ngawangga, sedya pamit kaliayan ingkang raka Dewi Surtikanthi.

Karna: ..kakanda meskipun hanya selama mata berkedip, hari ini minta diri kembali ke Ngawangga. Perlu berpaminatn dengan kakakmu Dewi Suryikanthi.

Penggunaan sapaan raka pada kutipan (20) menunjukkan bahwa sapaan raka dapat menunjukkan jenis kelamin lakilaki dan perempuan. Sistem ini berlaku pula pada kata sapaan ndara, gusti, yayi, dan adhi.

\section{c. Sistem dan fungsi Sapaan yang Ditentukan oleh Aspek Setting}


Sistem sapaan yang ditentukan oleh aspek setting di bagi dalam tiga kriteria. Kriteria pertama adalah setting tempat, kedua setting waktu, dan ketiga suasana. Sistem sapaan yang ditentukan oleh tempat menimbulkan sistem sapaan yang bersifat resmi dan santai. Sapaan yang bersifat resmi misalnya adegan yang digunakan dalam adegan kenegaraan seperti Janturan. sapaan yang di gunakan di dalam adegan janturan dipilih dipilih yang bersifat resmi yaitu sapaan para rakyat, punggawa kerajaan dan raja. Sapaan yang bersifat hubunga kerabat pada adegan tersebut agak dikesampingkan. Berikut ini kutipan sapaan dalam adegan janturan.

(21) Duryudana: paman sengkuni, mboya dados likitaning penggalih pekenira, pekenira manisa wenten majeng wenten ngarsa putra pekenira, paman paman Harya.

Duryudana: 'paman Sengkuni, jangan menjadikan sedihnya hatimu, kamu aku panggil menghadap dihadapan ananda, paman paman Harya'.

Sapaan pada kutipan di atas adalah sapaan Duryudana yang menyapa patih Sengkuni dengan sapaan resmi yaitu pekenira. Patih Sengkuni menyebut dirinya dengan abdi dalem 'hambamu'. Sapaan yang digunakan dalam suasana resmi dan tempat resmi seperti ini tidak mungkin akan berubah dengan sapaan yang lain.

Setting waktu juga mempengaruhi seorang okoh dalam memilih jenis sapaan. Jenis-jenis sapaan tersebut dapat dipilih pada kutipan berikut.

(22) Kartadendha : eeee, huh huh Pamoan kula nungsung werta Man, Man.

Kartadendha: 'Eeee, huh huh pamoan saya minta kabar Man, Man'.

(23) Wikathabala: Ana satriya ngaglak ana tengahing paprangan sapa he?
Wikathabala: 'Ada satriya berdiri di tengahtengah pertempuran siapa he?

Kutipan di atas yang menunjukkan waktu dan suasana adegan alun-alun adalah kutipan (22), sedangkan kutipan (23) menunjukkan adegan di medan perang. Pemilihan jenis sapaan pada (22) terlihat lebih seenaknya dan tidak peduli dengan sapaan santun. Berdasarkan contoh kutipan di atas jelas terlihat bahwa waktu dan suasana saling mengisi dalam menentukan aspek penentu sistem sapaan.

\section{d. Sistem dan Fungsi Sapaam yang Ditentuksn oleh Aspek Penghormatan}

Sistem sapaan jenis ini pemilihannya didasari oleh aspek penghormatan. Jenis sapaan yang dugunakan berupa sapaan penghormatan. Misalnya menyapan dengan gelar, jabatan dan kata ganti honorifik atau kata ganti atau kata ganti tingkat krama inggil. Sapaan ini berfungsi untuk menghormati orang yang disapa. Perhatikan kutipan berikut.

(24) Semar: Mesthinipun ndara Janaka taksih enget sabdanipun keng eyang Sinuwun Praba Maswapati

Semar: 'mestinta ndara Janaka masih ingat sabda kakekm Sinuwun Prabu Maswapati'.

(25) Surtikanthi: Penpundhen kula winten madya pada sang Adipati, kepareng kula nyaosaken pambagya raharja rawuh paduka..

Surtikanthi: 'Orang yang sangat aku hormati dan aku ikuti di dunia sang Adipati, perbolehkanlah saya menyampaikan ucapan selamat datang atas kehadiran paduka...

(26) Maswapati: Putu prabu Bathara Kresna padha kanthi..

Maswapati: 'Cucu Prabu Bathara Kresna dengan... 
Sapaan pada kutipan-kutipan di atas dipilih atas dasar aspek penghormatan atas orang yang disapa. Pada kutipan (24) dipilih jenis sapaan penghormatan berupan kata sapaan ndara 'tuan'. Kata ini dipilih karena penyapa adalah berstatus abdi, sehingga harus menyapa dengan penghormatan terhadap majikannya. Pada kutipan (25) Surtikanthi menyapa suaminya dengan sapaan honorifik yang sangat panjang yaitu Penpundhen kula winten madya pada sang Adipati. Sapaan ini berfungsi untuk menunjukkan betapa Surtiksmthi sangat hormat, tergantung pada suaminya, sehingga suaminya adalah segala-galanya di dunia. Sapaan ini muncul karena konteks kultural bahwa tupe khas wanita Jawa yang sangat ideal adalah wanita yang patuh, setia dan menyegalakan suaminya seperti Surtikanthi tersebut. Adapun kutipan (26) adalah penghormatan seorang kakek yang berkedudukan raja terhadap cucu yang brkedudukan raja dan berkharisma Dewa, maka sapaan yang dipilih adalahWayah Prabu Bathara Kresna. Kata bathara adalah penanda sapaan dewa, sedangkan letak penghormatan sapaan tersebut adalah penyebutan gelar dan titisan yaitu Prabu dan Bathara.

\section{e. Sistem dan Fungsi Sapaan yang Ditentukan oleh Aspek Pelaku/Pekerjaan}

Sistem sapaan ini jenisnya menunjukkan ciri pelaku kerja atau profesi seseorang yang disapa. Jenis sapaan mengacu pada jenis karya yang dilakukan atao profesi orang yang disapa. Berikut ini contoh kutipannya.

(27) Gareng: slung slung ,wah sing ngogong galak

Gareng: slung slung, aduh penabuh gongnya galak'

Sapaan pada kutipan (27) dipilih berdasarkan aspek profesi yaitu tukang gong. Sapaanya adalah sing ngegong, kata sing menunjukkan orang dan ngegong menunjukkan pekerja orang disapa.

\section{PENUTUP}

Berdasarkan uraian hasil dan pembahasan di atas, dapat disimpulkan bahwa terbentuknya sistem sapaan dalam wayang kulit ditentukan oleh 12 aspek penentu hubungan. Adapun jenis sapaan yang terdapat dalam wayang kulit terdiri dari 28 jenis sapaan. Adapun fungsi sapaan dalam wayang kulit terdiri dari 11 fungsi. Selain hal-hal diatas, adalah jenis sapaan dewa, sapaan bagongan, Hastina, dan sapaan honorifik untuk raja, permasiuri dan patih. Ciri khas sapaan bagongan Hastina erletak pada spaan raja terhadap patih dan orang yang dirormati raja.

Bagi para peneliti lain disarankan untuk mengkaji cerita, gaya dan dalang yang berlainan, khususnya gaya yang berbeda, karena dengan ditelitinya gaya berbeda pasti akan ditemukan sistem, jenis dan fungsi sapaan yang dapat diharapkan akan melengkapi penelitian ini.

Ada hal yang dapat diambil pelajaran bagi pemerhati pakeliran dan para seniman wayang bahwa untuk menciptakan dan memahami watak khas tokoh-tokoh wayang, pencipta dan penikmat harus mampu masuk kedalam alur cerita dan mengandaikan dirinya sebagai penyapa dan yang disapa, dan tidak bisa sebagai penyapa atau yang disapa saja.

\section{DAFTAR PUSTAKA}

Chaica, Elaine. 1982. Language The Sosia Mirror. Rowley: Newbury House Publishers, Inc.

Crystal, David. 1980. A Dictionsry of Linguistics and Phonetics. Massachusetc: Basil Black Well.

Ervin-Tripp, Susan. 1972. "On Sociolonguistic Rules: Alternation adn Co-occurrence”. Dalam Gumperz, Jhon J. 1972. Directions In Sociolinguistics The Ethnography of 
Communication. Mew York: Holt, Rinehart and Winston, Inc.

Halliday, Ruqaiya Hasan. 1980. Text and Context dalam Asrudin Barori Tou. 1994. Bahasa Konteks dan teks aspek-aspek Bahasa Dalam Pandangan Semiotik Sosial. Yogyakarta: Gadjah Mada University Press.

Kartomihardjo, Suseno. 1988. Bahasa Cermin Kehidupan Masyarakat. Jakarta: PPLPTK, Depdikbud.

Kridalaksana, Harimurti. 1984. Kamus Lisnguistk. Jakarta: Gramedia.

Mudjanattitomo, ddk. 1977. Pedhalangan Ngayogyakarta Ngayogyakarta: Jilid Yayasan
Sri Mulyono. 1989.Simbolisme dan Mistikisme dalam wayang. Jakarta: CV Haji Masagung.

Supriyanto, Hendrikus. 1986. Bentuk Sapaan Bahasa Jawa Dialek Jawa Timur. Jakarta: Pusat Pembinaan dan Pengembangan Bahasa Departemen Pendidikan dan Kebudayaan.

Tannen, Deborah. 1996. Seni Komunikasi Efektif Membangun Relasi dengan membina gaya Percakapan. Jakarta: Gramedia.

Wijana, I Dewa Putu. 1991. The of Term Of Address in Bahasa Indonesia. Yogyakarta: Fakultas Sastra Universitas Gadjah Mada.

Habirandha. 